\title{
IN VIVO MRI BIOCOMPATIBILITY EVALUATION OF FUNCTIONALIZED CARBON FIBERS IN REACTION WITH SOFT TISSUES
}

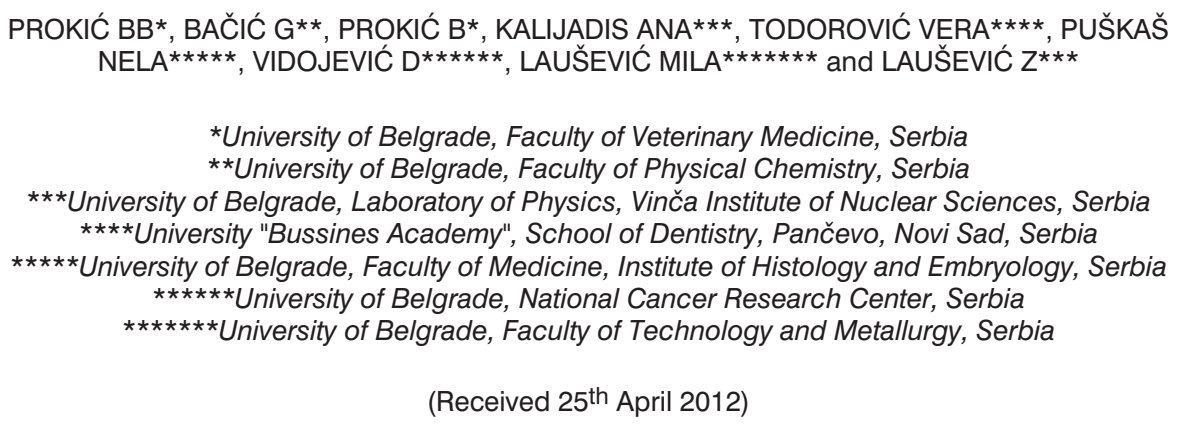

In modern medicine implants are very important and so is their design and choice of materials. Almost equally important is the choice of imaging technique used to in vivo monitor their fate and biocompatibility. The aim of this study was to evaluate the ability of magnetic resonance imaging (MRI) in monitoring the biocompatibility of two newly designed carbon fibers. We have analyzed the interaction of surface functionalized carbon fibers (basic and acidic) with muscle and subcutaneous tissues of rabbits. MRI techniques showed to be useful in longitudinal monitoring of the surrounding tissues, assessment of biocompatibility of new implants, and in the distinction of in vivo surgical edema from inflammation. Histopathology confirmed $M R I$ results, thus showing that $M R I$ has a great potential for in vivo studies of such materials.

Key words: carbon fiber implants, functionalization, $M R I$

\section{INTRODUCTION}

Carbon-based implant materials are well accepted by the biological environment (Blazewicz, 2001). Most of the studies on carbon fiber implants confirm that carbon fibers do not inhibit tissue growth, and thus can act as a scaffold for tissue proliferation (Forster et al., 1978). Scaffolds play a pivot role in the tissue engineering paradigm by providing temporary structural support, guiding cells to grow, assisting the transport of essential nutrients and waste products, facilitating the formation of functional tissues and organs (Sitharaman et al., 2008), and functions as a delivery base for bioactive molecules necessary for the formation of new bone tissue (Ma, 2004; Mistry et al., 2005; Mistry et al., 2006). One of the earliest medical uses of carbon fibers was the replacement or repair of ligaments and tendons (Forster et al., 1978; Kilfoil et al., 1983; Amis et al., 1984; 
Jenkins, 1985). Appropriately chosen parameters of the chemical treatment of carbon fibers can lead to a desired modification of their mechanical properties in order to obtain a suitable material for ligament or tendon prostheses or to their biological properties for different medical applications (Czajkowska and Blazewicz, 1997). Controlled modification of the surface of carbon biomaterials can change the effect or function of immunological cells response (Czajkowska and Blazewicz, 1997; Karen et al., 2003). Properties of carbon fiber (CF) are important for medical applications and are related to the physical and chemical structure of their surface, as well as to the broad possibility of customizing their mechanical properties, so that the fibers should be comparable with the replaced tissues (Rajzer et al., 2010).

In order to appreciate the full benefit of designer carbons, it is necessary to develop the chemistry for functionalizing the porous carbon surfaces (Stein et al., 2008). Careful oxidation enhances the wettability of the pores by polar solvents and increases the fraction of micropores and the surface area of carbon. The most commonly used oxidant for carbonaceous materials is an aqueous solution of either concentrated or diluted nitric acid (Otake and Jenkins, 1993; Pradhan and Sandle, 1999).

Oxidation with nitric acid is a highly efficient process for the generation of surface functional groups. This oxidation technique has also been applied successfully for the surface modification of ordered mesoporous carbons, resulting in carboxyl groups (Lu et al., 2005; Li et al., 2006; Vinu et al., 2007; Bazula et al., 2008).

Magnetic resonance imaging (MRI) is arguably the best in vivo imaging technique and has been extensively used in studies of experimental animals (Gavin and Bagley, 2009). MRI has been often used for evaluating the placement of implants (prosthetic devices and drug delivery systems), their biocompatibility and degradation (Belmatoug et al., 1996; Mader et al., 1997; Ernstberger et al., 2007; Gavin and Bagley, 2009; Ernstberger et al., 2012). Implants themselves give no signal on MRI (except some silicon implants) since they have no mobile hydrogen atoms or no hydrogen atoms at all. This is not the problem in the evaluation of their placement or reaction of surrounding tissue to implants. The general problem encountered in studies of implants is that they have different magnetic susceptibility from biological tissues which results in a different magnetic field in their surroundings (Gavin and Bagley, 2009). This creates image distortion which can be so severe that resulting images may become useless. The extent of distortion depends on the implant material and is generally very pronounced for metals. Thus, the use of non-metalic implant materials such as carbon has become increasingly widespread in clinical routine.

Histopathology is the gold standard in the evaluation of tissue response to implants. The rationale for using MRI in such studies lays in the ability to assess tissue response in vivo. This is especially valuable when studying new types of implants in experimental animals. MRI can evaluate the biocompatibility in noninvasive manner over prolonged periods of time which can greatly reduce the number of animals needed for longitudinal studies. 
Acta Veterinaria (Beograd), Vol. 62, No. 5-6, 683-696, 2012.

In this study we have analyzed biocompatibility of two types of functionalized carbon fibers. MRI was used to visualize soft tissues implants, follow interaction soft tissue-implant interface, and to detect the location and extent of inflammation. Histopathology was performed at the end and results were compared with MRI results.

\section{MATERIALS AND METHODS}

\section{Preparation of implants}

We used commercial high-strength carbon fibers, Torayca, T300B, with 6000 tiberin bundle. Carbon fiber implants were functionalized at the Laboratory of Physics in the Vinča Institute of Nuclear Sciences, Belgrade. Implants were made of 8 bundles of carbon fiber, which made an implant with 48000 fibers.

The chemical treatments (surface functionalization) involved submerging the as-received carbon fibers in boiling $2 \mathrm{M} \mathrm{HNO}_{3}(\mathrm{Cl}-\mathrm{A})$ or $2 \mathrm{M} \mathrm{KOH}(\mathrm{Cl}-\mathrm{B})$ solution for two hours. Samples were then thoroughly washed with distilled water to neutral $\mathrm{pH}$, and dried at $80^{\circ} \mathrm{C}$ for $24 \mathrm{~h}$. All samples were stored in the dessicator until used.

The oxygen groups on a carbon material surface that has acidic or basic properties are determined by acid-base titration methods (Barton et al., 1997). The amount of acidic sites and basic sites were determined by mixing a small quantity $(0.1 \mathrm{~g})$ of carbon fibers with $25 \mathrm{ml}$ of $0.1 \mathrm{M} \mathrm{NaOH}$ or $0.1 \mathrm{M} \mathrm{HCl}$, in $50 \mathrm{~mL}$ beakers. The beakers were sealed and shaken for $24 \mathrm{~h}$. The solutions were then filtered and titrated with $0.1 \mathrm{M} \mathrm{HCl}$ or $0.1 \mathrm{M} \mathrm{NaOH}$.

The point of zero charge (PZC) of the carbon fibers was determined by mass titration (Noh and Schwarz, 1990) by placing various amounts $(0.05,0.1,0.5,1$ and $10 \%$ by weight) of carbon fibers in $10 \mathrm{~cm}^{3}$ of $0.1 \mathrm{M} \mathrm{KCl}$ solution (prepared using preboiled water to eliminate $\mathrm{CO}_{2}$ ). The beakers were held in $\mathrm{N}_{2}$ atmosphere to eliminate any contact with air. They were then placed in a thermostat shaker overnight. The equilibrium $\mathrm{pH}$ values of the mixtures were then measured with WTW inoLab pH level 1, Germany. The limiting $\mathrm{pH}$ value was taken as the PZC.

\section{Animals}

Work with animals was approved by The Ethics committee of The Faculty of Veterinary Medicine, University of Belgrade. For implanting carbon implants in different types of tissue we have used experimental rabbits (chinchilla), purchased from the Experimental section of The Military Medical Academy in Belgrade. Rabbits were between 4 and 5 months old. Surgery operation was performed in the aseptic operation room at the Clinic for Surgery, Orthtopedy and Ophthalmology of the Faculty of Veterinary Medicine, University of Belgrade. After operation, animals were maintained in the experimental ward of the faculty clinic.

\section{Surgery}

The process of implantation of carbon implants into back muscle and subcutaneous tissue was done in general anesthesia. For anesthesia we have 
Prokić BB et al.: In vivo MRI biocompatibility evaluation of functionalized carbon fibers in reaction with soft tissues

used a combination of ketamine $35 \mathrm{mg} / \mathrm{kg}$ and xylazine $5 \mathrm{mg} / \mathrm{kg}$. Eight animals were included in the experiment.

Prior to implantation the top of the implant fiber bundle was temporarily fixed with epoxy resin in the shape of an arrow to facilitate manipulation with fibers. For intramuscular implantation, an initial incision, $6 \mathrm{~cm}$ in length, was made along the spine in the thoracolumbar region. Just below the section is the backbone, and with its left and right side is $\mathrm{m}$. longissimus dorsi. On the left side of the muscle we made an incision, $0.5 \mathrm{~cm}$ deep through which we entered with an alligator forceps into the muscle. The forceps was passed through the middle of the back muscles, parallel to the spine, $3-4 \mathrm{~cm}$ in length in cranial direction. At the top of the instrument we made a cut which allowed access to the top of the instrument. Accepting the top $\mathrm{Cl}-\mathrm{A}$, and returning the instrument to its original position, $\mathrm{Cl}-\mathrm{A}$ was placed through the muscle. The implant was placed through the middle of the muscle (Figure 1). The same procedure was done on the right side of the muscle only with Cl-B. For subcutaneous implantation an initial $4 \mathrm{~mm}$ incision on the skin was made and essentially the same procedures were used as in the case of intramuscular implantats. Muscle and skin sutures were done with a 4/0 resorbable thread.

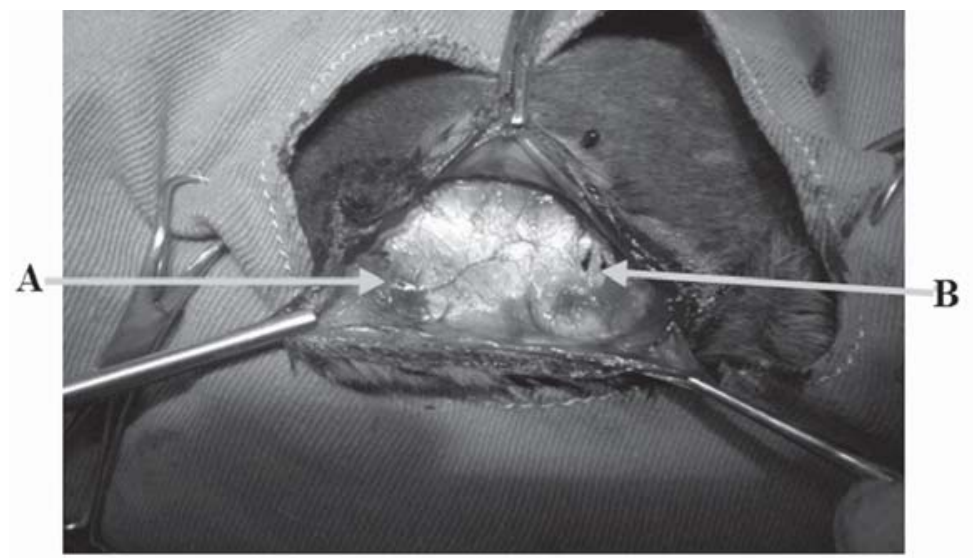

Figure 1. Muscle longissimus dorsi of the rabbit with carbon implant implanted trough the middle of the muscle. Arrows mark the beginning $(A)$ and the end $(B)$ of implant

During the course of the study, all animals have been under constant monitoring. Before and after surgery they had free access to food and water. Every day physical condition, behavior, and body temperature were monitored. No signs of inflammation were noticed close to the surgical wound. Wounds healed without edema and exudate. Animals were sacrificed (prolonged anesthesia with ketamine and xylazine) three weeks after implantation (i.e. after completing MRI) and selected tissues were collected for histopathological analysis. 
Acta Veterinaria (Beograd), Vol. 62, No. 5-6, 683-696, 2012.

\section{MRI}

MRI scans were performed using a $1.5 \mathrm{~T}$ imager (Avanto, Siemens, Germany) using a commercial knee coil. Two MRI sequences were generally employed: Turbo spin echo T1W $(\mathrm{TR}=11 \mathrm{~ms}, \mathrm{TE}=820 \mathrm{~ms})$ and T2W $(\mathrm{TR}=$ $81 \mathrm{~ms}$, TE $=8620 \mathrm{~ms}$ ), although some other sequences such as T2W TrueFISP, T2W SPACE, and T1W FLASH were tested while optimizing the imaging protocol. The longest imaging time was 45 min per animal and animals were anesthetized during the MRI examination (ketamine $35 \mathrm{mg} / \mathrm{kg}$ and xylazine $5 \mathrm{mg} / \mathrm{kg}$ ). Contrast agent Gd-DTPA (Schering, Germany) was administered into v.saphena at dose of $0.2 \mathrm{mmol} / \mathrm{kg}$. Animals underwent MRI at 1, 2, and 3 weeks after surgery.

Prior to imaging we produced gel phantoms which are frequently used to mimic soft tissues on MRI and to assess artifacts produced by implants (Bačić et al., 1993; Bačić et al., 2001). Phantoms were made using $2 \%$ agar-agar gel in the $300 \mathrm{~mL}$ plastic bottles into which implants were inserted. These were used to optimize imaging techniques prior to animal imaging.

\section{Histopathological analysis}

The tissue samples removed from the implant area together with adjoining tissues were collected, fixated in $10 \%$ buffered formalin, routinely embedded in Paraplast and cut into $5 \mu \mathrm{m}$ thick sections. Tissue sections were stained with hematoxylin and eosin (H\&E). Histopathological analysis of the tissue surrounding and growing between the carbon fibers was made by light microscope Olympus BX41. Investigation of biocompatibility of carbon fibers was done by using international standards ISO-10993-6:2007 and ISO-10993-10:2002 with appropriate modifications (Upman and Muench, 2004; Marković et al., 2009).

Semiquantitative assessment of histological changes in rabbits with implanted fibers includes the changes in the epithelium (ranging from normal epithelium, through cell degeneration and metaplasia to focal or generalized erosion) or muscle tissue (ranging from normal, through degenerated, to different intensity of necrosis) and evaluation of the degree of leukocyte infiltration, vascular congestion and edema. The presence of a fibrous capsule around the implant and its relative thickness were evaluated.

From the evaluation of histopathological changes irritation index (Irl) was estimated as a measure of the severity of tissue damage at the site of implantation.

\section{RESULTS AND DISCUSSION}

Changes of the surface chemistry resulting from $\mathrm{HNO}_{3}$ and $\mathrm{KOH}$ treatment are summarized in Table 1. It is clear that the chemical nature of surface functionality is significantly altered by nitric acid and potassium hydroxide treatments. The acidic nature of carbon materials was derived primarily from the oxygen-containing groups (mainly carboxylic, anhydrides, lactones and phenols). However, the surface basicity is related to the presence of oxygen-free Lewis sites and carbonyl, pyrone and chromene type structures at the edge of the carbon layers. (Kalijadis et al., 2011). The obtained results indicate that acidic groups formed by $\mathrm{HNO}_{3}$ treatment dominate the surface of the $\mathrm{Cl}-\mathrm{A}$, and this is 
Prokić BB et al.: In vivo MRI biocompatibility evaluation of functionalized carbon fibers in reaction with soft tissues

reflected in higher acidic/basic ratio and lower PZC value. Also oxidation treatment with $\mathrm{HNO}_{3}$ increased the total amount of surface functionalities. On the other hand, for $\mathrm{Cl}-\mathrm{B}$ sample, the potassium hydroxide treatment of carbon fibers resulted in a decrease of acidic surface groups and according to PZC value these fibers have low basic character.

Table 1. Surface chemistry characteristics of functionalized carbon fibers

\begin{tabular}{|c|c|c|c|c|}
\hline Type of fiber & $\begin{array}{c}\text { Acidic groups } \\
(\mathrm{mmol} / \mathrm{g})\end{array}$ & $\begin{array}{c}\text { Basic groups } \\
(\mathrm{mmol} / \mathrm{g})\end{array}$ & Acidic/Basic & PZC \\
\hline \hline $\mathrm{Cl}-\mathrm{A}$ & 0.5135 & 0.3040 & 1.7 & 5.3 \\
\hline $\mathrm{Cl}-\mathrm{B}$ & 0.1011 & 0.3843 & 0.3 & 8.5 \\
\hline
\end{tabular}

Figures 2 and 3 show MRI results obtained for gel phantoms. We used two types of implants to assess magnetic susceptibility of different preparations on various sequences: one with both tips glued to keep the implant straight (Figure 2) and the second one (without gluing) which more closely mimics the real situation of implants within tissues (Figure 3 ).

A

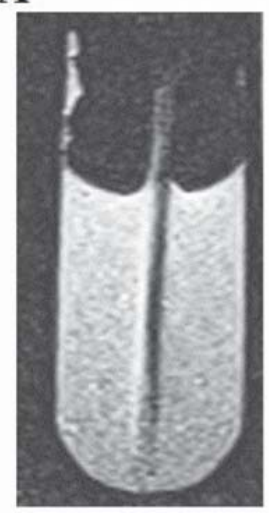

B

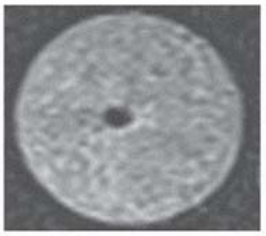

C

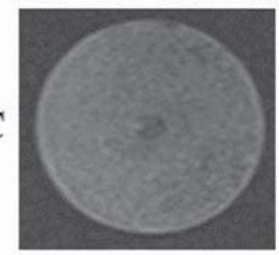

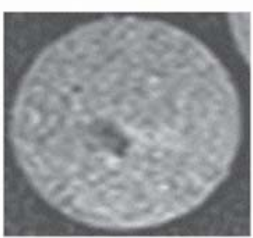
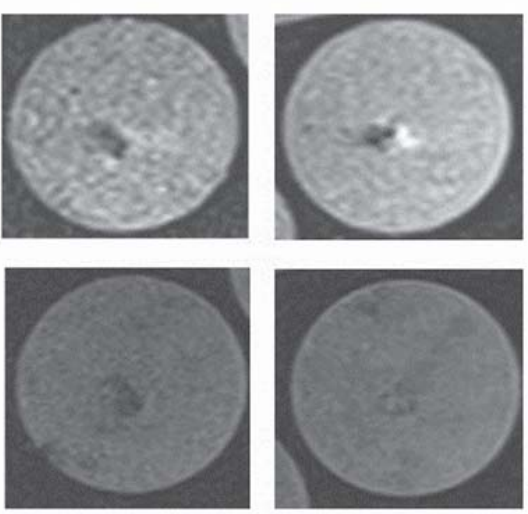

Figure 2. MRI images of gel phantoms with straight implants obtained approximately 36 hours after the preparation. A. T1W image of longitudinal slice through gel phantom for the straight implant. Top row - Perpendicular T1W images of acid-treated (Cl A), neutral (unmodified), base-treated (Cl-B) - from left-to-righ. Bottom row - T2W images of same samples. Frequency encoding direction is left-to-right

Carbon fibers do not have mobile hydrogen atoms thus they appear as a signal void (black area) on MRI (Figure 2A). It appears that the modifications of the surface of implants have no effect on the MRI appearance since the dimensions of the signal void are essentially the same for all three types of fibers (Figure 2B). Bright spots on images to the right of implants are typical susceptibility artifacts in frequency encoding direction (Bačić et al.,1993; Bačić et al., 2001; Gavin and 
Bagley, 2009). It also should be noted that appearance of implants on MRI does not reflect the real dimensions of implants since magnetic susceptibility artifacts enlarge the signal void beyond the actual size of the implant. However, the difference between the MRI diameter of implants and their actual size is only around $10 \%$. It is not surprising that the alteration of the surface of implants has no effect on their appearance on MRI, since that depends on the bulk susceptibility difference between implant and surrounding media. For example, an MRI study showed that implants made of carbon fibers reinforced polymers and titaniumcoated carbon-fiber-reinforced polymers produced artifacts, while implants made of titanium alone produce two-fold larger artifacts (Erstenberger et al., 2007). It is also important to note that implants are clearly visible on standard spin-echo images with a spatial resolution. Consequently, there is no need for using gradient-echo sequence which enhances susceptibility effects and are used when implants are too small for the available resolution (Bačić et al, 1993), but using gradient-echo can obliterate the signal from the tissue around the implant. Figure $3 \mathrm{C}$ shows that the signal void is not that clearly depicted as on T1W images which can be explained by partial penetration of water into implants during the time between the preparation and MRI.
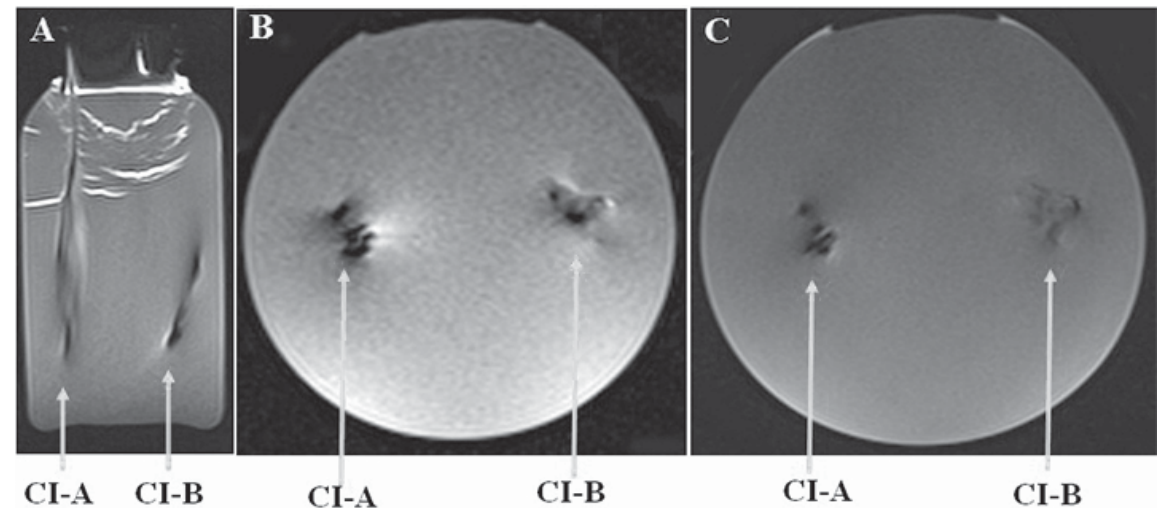

Figure 3. MRI images of gel phantoms with loose-ends implants obtained approximately 36 hours after the preparation. A. Longitudinal T1W image; Perpendicular: B - T1W image, $\mathrm{C}-\mathrm{T} 2 \mathrm{~W}$ image

Figure 3 shows MRI of implants without glued tips which is pertinent for in vivo situation. Irregular shapes of implant images on cross sections clearly show that implants departured from their original circular shape. Also, T2W images (Figure $3 \mathrm{C}$ ) indicates water penetration between 8 bundles of carbon fibers. Overall, these images showed difficulties associated with finding the appropriate cross section of all implants on a single slice when imaging rabbits.

Figure 4 illustrates the state of implants and the tissue reactions one week after implantation. Figures $4 \mathrm{~A}$ and $4 \mathrm{~B}$ show the visibility of all four implants (Cl-Bim, Cl-B-sc, and Cl-A-im, Cl-A-sc). All implants can be visualized on a single MRI slice, but with the precision that is insufficient for further analysis (Figure $4 \mathrm{C}$ ). It is 
Prokić BB et al.: In vivo MRI biocompatibility evaluation of functionalized carbon fibers in reaction with soft tissues

apparent that implants are better characterized on T1W images than on T2W images (compare Figures $4 \mathrm{~A}$ and $4 \mathrm{~B}$ ). Also, it is apparent that the shape of implants is variable ranging from almost round-like shape, to flattened shape $(\mathrm{Cl}-$ $\mathrm{B}-\mathrm{im}$ ) which may be the consequence of the implantation procedure, but also may reflect the influence of particular tissue on the implant. The most important feature are areas of increased signal intensity (hyperintensities, as compared to normal muscle tissue) around intramuscular implants visible on T2W images (Figure 4B) around intramuscular implants. Hyperintesities on T2W images signify the presence of area of increased water content in tissues (Gavin and Bagley, 2009). This is not visible on T1W images since water has a low intensity on these images. Hyperintensity areas on T2W images therefore depict edematous or inflammatory tissue which can be a consequence of trauma induced by surgery and/or inflammatory reaction of tissue to implants.
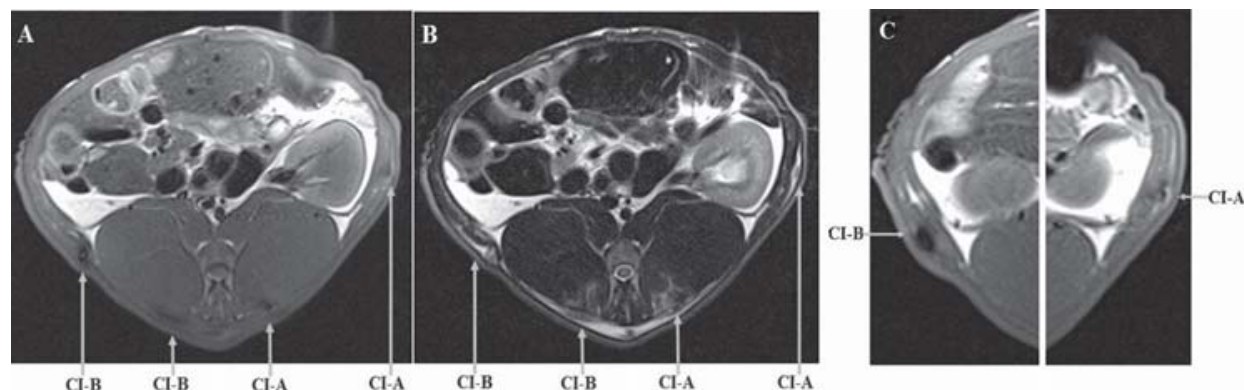

Figure 4. $\mathrm{MRI}$ images of rabbits with implanted $\mathrm{Cl}-\mathrm{A}$ i $\mathrm{Cl}-\mathrm{B}$ both intra muscularly or subcutaneously one week after implantation. A and B - T1W and T2W images of the same slice. C-T1W images of subcutaneous implants (left panel - Cl-B, right panel$\mathrm{Cl}-\mathrm{A})$

Figure 5 and 6 shows T2 weighted MRI at days 7, 14, and 21 after implantation. It should be noted that it is impossible to obtain identical slices in consecutive imaging since the position of animals is slightly different on each MRI exam. We therefore selected slices which best illustrate changes in tissue reaction during this period on one animal. Other animals qualitatively exhibited the same reaction to implants.
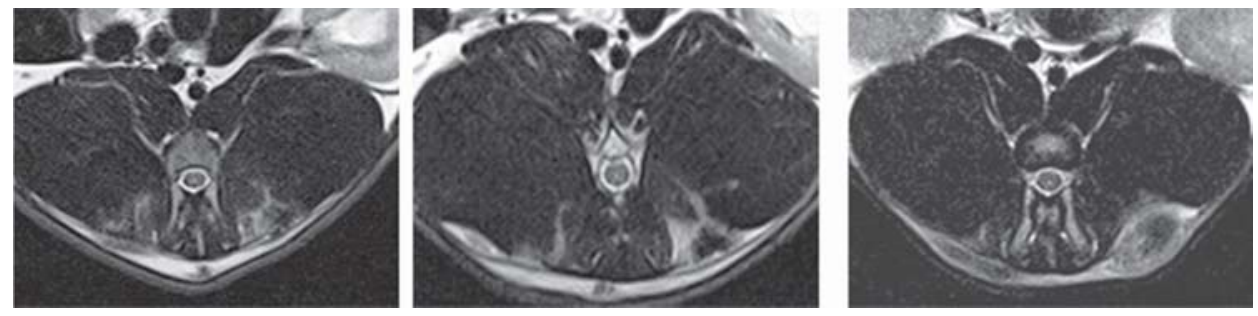

Figure 5. Longitudinal T2W MR images of muscle tissue response to implants on $7^{\text {th }}, 14^{\text {th }}$, and $21^{\text {st }}$ day after implantation 
Acta Veterinaria (Beograd), Vol. 62, No. 5-6, 683-696, 2012.

Figure 5 shows muscle tissue reaction after implantation. Hyperintensities on day 7 are visible around both $\mathrm{Cl}-\mathrm{A}$-im and $\mathrm{Cl}-\mathrm{B}$-im implants. Hyperintesities persist around $\mathrm{Cl}-\mathrm{B}-\mathrm{im}$ implants until day 21, while they almost disappeared around $\mathrm{Cl}-\mathrm{A}$-im implant except at the immediate surface of implant. It is reasonable to assume that hyperintensities around both implants on day 7 originate mostly from edematous tissue which is a consequence of trauma during implant application. However, hyperintensities around Cl-A-im implants on later images are likely to be caused by inflammatory reactions.
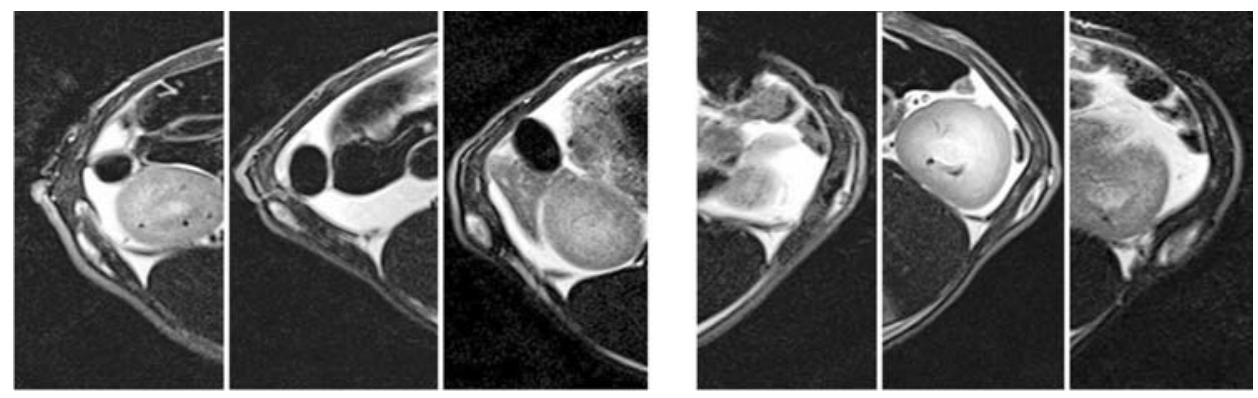

Figure 6. Longitudinal T2W MR images of subcutanous tissue response to implants at $7^{\text {th }}$, $14^{\text {th }}$, and $21^{\text {st }}$ day after implantation

Figure 6 shows tissue reactions on subcutaneous implantation. The situation is more or less similar to reaction in muscles, except that tissue reactions are less pronounced and that the difference of tissue reaction between $\mathrm{Cl}-\mathrm{A}$ and $\mathrm{Cl}-\mathrm{B}$ implants is also less pronounced than in the muscle, but progression of the size of hyperintensities around $\mathrm{Cl}-\mathrm{A}$ implants is clearly visible.

Probably the best method in assessment of inflammation and demonstration of differences in tissue reaction between $\mathrm{Cl}-\mathrm{A}$ and $\mathrm{Cl}-\mathrm{B}$ implants is the application of contrast agents (Figure 7). Areas of inflammation are generally hypointense to surrounding tissue on T1W MRI unless in the case of fresh hemorrhage where blood cell oxyhemoglobin can make inflammations slightly hyperintense, which seems to be the case here (Figure 7A). Contrast agents based on gadolinium complexes are intravascular, extracellular agents designed to depict areas of increased permeability of blood vessels. Accumulation of contrast in certain tissue is a sign of altered vascularity which is easily detected on postcontrast T1W images as a zone of high signal intensity, since gadolinium greatly enhance $\mathrm{T} 1$ relaxation times due to paramagnetic effect (Gavin and Bagley, 2009). Consequently, large area of signal enhancement around Cl-A-im implant clearly indicates pronounced inflammation around the implant, while a small area around $\mathrm{Cl}$-B-im implants indicates a mild reaction localized only at the surface of the implant. Reaction of tissue around subcutaneous implants is essentially the same; pronounced reaction around $\mathrm{Cl}-\mathrm{A}$ implants and mild or no reaction around $\mathrm{Cl}-\mathrm{B}$ implant. Contrast enhanced $\mathrm{MRI}$ essentially confirmed all 
findings and conclusions obtained by more conventional MRI imaging (Figures 5 and 6).
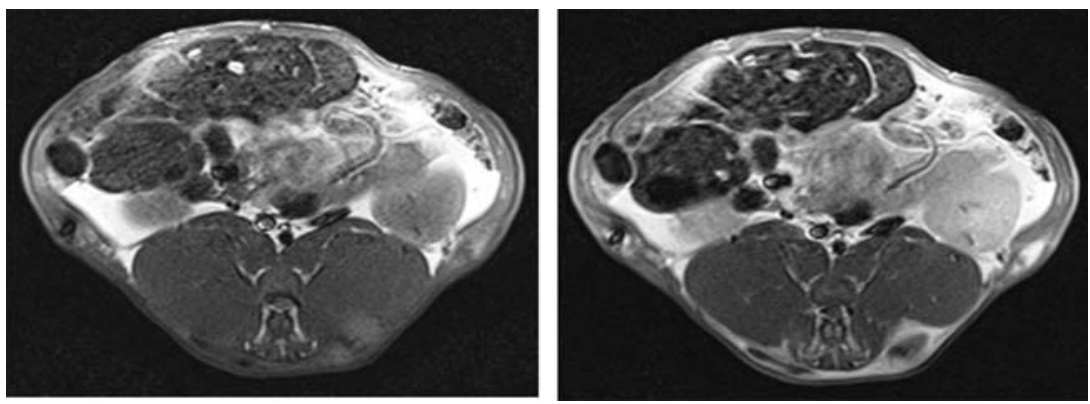

Figure 7. Contrast enhanced MRI of tissue response on day 21. A - T1W image prior to contrast injection (approximately the same slice as T2W image in Figure 6). B Postcontrast T1W image

Summarizing all MRI findings it can be concluded that carbon fiber implants with different treatment of their surface provoke different tissue response and that implants with basic surface sites are more biocompatible (provoke lower tissue reaction) than those with acidic surface sites.

Results obtained during sample collection and by histopathology (Figure 8) immediately after completion of third MRI screening essentially confirm MRI findings. Visual inspection of samples showed the presence of mild inflammation in both muscles and subcutaneous tissue with Cl-B implants, while the inflammation was more pronounced in both muscles and subcutaneous tissue with $\mathrm{Cl}-\mathrm{A}$ implants.

Figure 8 ( $A$ and $C$ ) show evidently preserved structures of the dermis which surround the implanted fibers. Granulation tissue is present between fibers, with eosinophils, giant multinuclear cells, lymphocytes and rare neutrophils. The difference Figure 8 ( $B$ and $D$ ) shows a structure of muscle tissue which surrounds the implanted fibers. Granulation tissue is present both between and around the fibers. Eosinophils, giant multinuclear cells, lymphocytes and neutrophils were noticed in the implanted area and between the fibers.

Semi-quantitative assessments of all above mentioned parameters can be summarized in the irritation index (Irl). Score of this evaluation show mild irritation index and mild response of tissue for both type of fibers (Cl-A and $\mathrm{Cl}-\mathrm{B}$ ) implanted subcutaneously or intramuscularly. Grading system for microscopic examination of tissue reaction after implantation of $\mathrm{Cl}-\mathrm{A}$ in the subcutaneous tissue gave $\mid \mathrm{rl}=$ 8,33 , while the tissue reaction with $\mathrm{Cl}-\mathrm{B}$ was $\mathrm{Irl}=7.0$. Likewise, grading system for muscle tissue reaction showed $\mathrm{Irl}=8.8$ for $\mathrm{Cl}-\mathrm{A}$ and $\mathrm{Irl}=7.8$ for $\mathrm{Cl}-\mathrm{B}$.

These results essentially confirm MRI findings that $\mathrm{Cl}-\mathrm{A}$ implants provoke larger tissue response than $\mathrm{Cl}-\mathrm{B}$ implants. The difference of tissue response between these implants is less pronounced on histopathology than on MRI, while it has to be remembered that MRI is assessing wide areas of tissues around 
Acta Veterinaria (Beograd), Vol. 62, No. 5-6, 683-696, 2012.

Prokić BB et al.: In vivo MRI biocompatibility evaluation

of functionalized carbon fibers in reaction with soft tissues

implants, while histopathology assesses their immediate vicinity. Also, histopathology confirmed penetration of water/cells into implant bundles, which was noticeable on numerous images. Overall, our results show that the process of surface functionalization is very important because it significantly changes the tissue response. Similar results of tissue reaction upon acid/base treatment of implanted carbon fabric has been observed before (Blazewicz and Paluszkiewicz, 2001), although the study has been performed on different tissues.
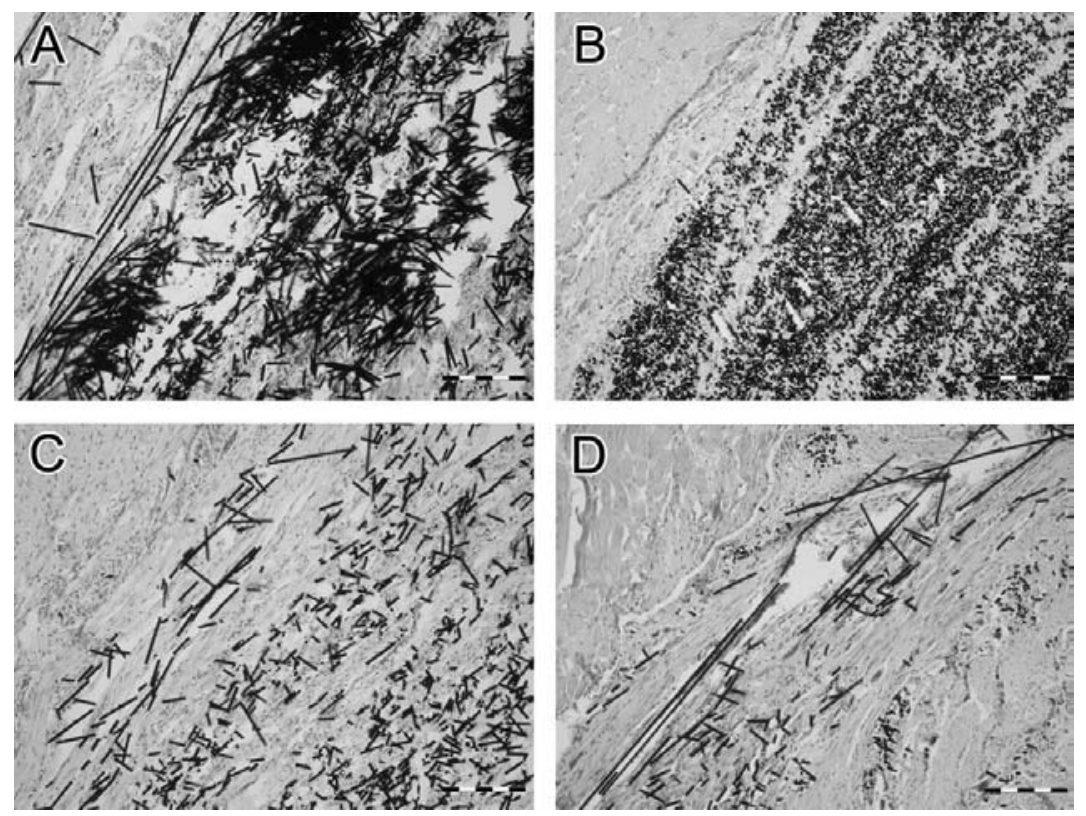

Figure 8. Histopathology of tissues with implanted carbon fibers. (A) $\mathrm{Cl}-\mathrm{A}$ in subcutaneous tissue; (B) Cl-A in muscle tissue; (C) Cl-B in subcutaneous tissue; (D) Cl-B in muscle tissue. (H\&E)

\section{CONCLUSIONS}

Our study demonstrated the ability of MRI to assess the tissue response to carbon implants. MRI analysis of tissue reaction to two carbon materials with different surfaces implanted subcutaneously and intramuscularly showed that it is possible to distinguish various tissue reactions (edema/inflammation) and to distinguish tissue reactions to different types of implants. Histopathology confirmed MRI results proving the usefulness of MRI in follow-up studies of biocompatibility of implants, especially in studies where new types of implants have to be evaluated. 
ACKNOWLEDGMENT:

We acknowledge the support to this work provided by the Ministry of Education and Science of Serbia, projects III 45006 and III 41005.

Adress for correspodence:

Dr Prokić Bogomir Bolka

Faculty of Veterinary Medicine

University of Belgrade

Bulevar Oslobodjenja 18

11000 Belgrade, Serbia

E-mail: bbprokic@gmail.com

\section{REFERENCES}

1. Amis AA, Campbell JR, Kempson SA, Miller JH, 1984, Comparison of the structure of neotendons induced by implantation of carbon or polyester fibers, J Bone Joint Surg, 66, 131-9.

2. Bačić G, Poleksić Lj, Lavrnić S, Mirkov Z, Apostolidis G, 2001, Artifacts in Magnetic Resonance Imaging: Magnetic field inhomogeneity artifacts - how they can be recognized, avoided and utilized, Radiol Arch Serb, 10, 7-21.

3. Bačić G, Liu KJ, O'Hara JA, Harris RD, Szybinski K, Goda F et al., 1993, Oxygen tension in murine tumor, A combined EPR and MRI study, Magn Reson Med, 30, 568-72.

4. Barton SS, Evans MJB, Halliop E and MacDona JAF, 1997, Acid and basic sites on surface of porous carbon, Carbon, 35, 1361-66.

5. Bazula PA, Lu AH, Nitz JJ, Schueth F, 2008, Surface and pore structure modification of ordered mesoporous carbons via a chemical oxidation approach, Micropor Mesopor Mater, 108, 26675.

6. Belmatoug N, Crémieux AC, Bleton R, Volk A, Saleh-Mghir A, Grossin M et al., 1996, A new model of experimental prosthetic joint infection due to methicillin-resistant Staphylococcus aureus: a microbiologic, histopathologic, and magnetic resonance imaging characterization, J Infect Dis, 174, 414-7.

7. Blazewicz M, Paluszkiewicz C, 2001, Characterization of biomaterials used for bone regeneration by FTIR spectroscopy, J Mol Struct, 563-564,147-52.

8. Blazewicz M, 2001, Carbon materials in the treatment of soft and hard tissue injuries, Eur Cells Mater, 2, 21-9.

9. Czajkowska B, Blazewicz M, 1997, Phagocytosis of chemically modified carbon materials, Biomaterials, 18, 69-74.

10. Erstenberg T, Heindrich G, Klingers HM, Baums MH, 2012, Score based assessment of implantrelated post fusion MRI artifacts focused on different interbody disc spacers, An in vitro study, Open J Clin Diagnos, 2, 23-9.

11. Erstenberger T, Buchhorn G, Baums MH, Heindrich G, 2007, In-vitro MRI detectability of interbody test spacers made of carbon fibre-reinforced polymers, titanium and titanium-coated carbonfibre-reinforced polymers. Acta Ortoph Belg, 73, 244-9.

12. Forster IW, Ralis ZA, McKibbin B, Jenkins $D H R$, 1978, Biological reaction to carbon fiber implants, Clin Orthop Rel Res, 131, 299-307.

13. Gavin P, Bagley R, 2009, Practical Small Animal MRI, Wiley-Blackwell, Ames.

14. Jenkins $D H R, 1985$, Ligament induction by filamentous carbon fibre, Clin Orthop, 197, 86-90.

15. Kalijadis A, Vukčević $M$, Jovanović Z, Laušević $Z$, Laušević $M, 2011$, Characterisation of surface oxygen groups on different carbon materials by the Boehm method and temperatureprogrammed desorption, J Serb Chem Soc, 76, 757-68.

16. Karen SE, Price RL, Haberstroh KM, Webster TJ, 2003, Carbon nanofiber surface roughness increases osteoblast adhesion, MRS, 774.

17. Kilfoil BM, Hesby RA, Pelleu J, 1983, The tensile strength of a composite resin reinforced with carbon fibers, $J$ Pros Dent, 40-3. 
Acta Veterinaria (Beograd), Vol. 62, No. 5-6, 683-696, 2012.

18. Li H, Xi HA, Zhu S, Wen Z, Wang R, 2006, Preparation, structural characterization, and electrochemical properties of chemically modified mesoporous carbon, Micropor Mesopor Mater, 96, 357-62.

19. Lu AH, Li WC, Muratova N, Spliethoff B, Schueth F, 2005, Evidence for C-C bond cleavage by $\mathrm{H}_{2} \mathrm{O}_{2}$ in a mesoporous CMK-5 type carbon at room temperature, Chem Commun, 41, 5184-6.

20. Ma PX, 2004, Scaffolds for tissue fabrication, Mater Today, 7, 30-40.

21. Mader K, Bačić G, Domb A, Elmalak O, LangerR, Swartz HM, 1997, Noninvasive in vivo monitoring of drug release and polymer erosion from biodegradable polymers by EPR spectroscopy and NMR imaging, J Pharm Sci, 86, 126-34.

22. Marković D, Kojić Z, Marinković D, Danilović V, Radovanović A, Janaćković $\bigoplus, 2009$, Histological and immunohistochemical evaluations of rat soft tissue response to bioceramical implants, Acta Vet (Beograd), 59, 243-53.

23. Mistry AS, Shi X, Mikos AG, 2006, Nanocomposite scaffolds for tissue engineering, Biomedical engineering handbook, Bronzino J editor, Boca Raton, CRC Press, 40-1.

24. Noh J, Schwarz JA, 1990, Estimation of surface ionization constants for amphoteric solids, J Colloid Interface Sci, 139, 139-48.

25. Otake Y, Jenkins RG, 1993, Characterization of oxygen-containing surface complexes created on a microporous carbon by air and nitric acid treatment, Carbon, 31, 109-21.

26. Pradhan BK, Sandle NK, 1999, Effect of different oxidizing agent treatments on the surface properties of activated carbons, Carbon, 37, 1323-32.

27. Rajzer I, Menaszek E, Bacakova L, Rom M, Blazewicz M, 2010, In vitro and in vivo studies on biocompatibility of carbon fibres, J Mater Sci Mater Med, 21, 2611-22.

28. Sitharaman B, Shi X, Walboomers F, Liao H, Cuijpers V, Wilson LJ et al., 2008, In vivo biocompatibility of ultra-short single-walled carbon nanotube /biodegradable polymer nanocomposites for bone tissue engineering, Bone, 43, 362-70.

29. Stein A, Wang Z, Fierke MA, 2008, Functionalization of Porous Carbon Materials with Designed Pore Architecture, Adv Mater, 21, 265-93.

30. Upman PJ, Muench T, 2004, Comprehensive Scoring System for Biomaterial Implants, Amer College of Toxicology Presentation, Int J Toxicol, 23, 384.

31. Vinu A, Hossian KZ, Srinivasu P, Miyahara M, Anandan S, Gokulakrishnan N et al., 2007, Carboxymesoporous carbon and its excellent adsorption capability for proteins, $J$ Mater Chem, 17, 1819-25.

32. Mistry AS, Mikos AG, 2005, Tissue engineering strategies for bone regeneration, Adv Biochem Eng Biotechnol, 94, 1-22.

\title{
IN VIVO MRI PROCENA BIOKOMPATIBILNOSTI FUNKCIONALIZOVANIH KARBONSKIH VLAKANA U REAKCIJI SA MEKIM TKIVOM
}

\author{
PROKIĆ BB, BAČIĆ G, PROKIĆ B, KALIJADIS ANA, TODOROVIĆ VERA, PUŠKAŠ NELA, \\ VIDOJEVIĆ D, LAUŠEVIĆ MILA i LAUŠEVIĆ Z
}

\section{SADRŽAJ}

U modernoj medicine implanti su veoma važni, kao i njihovo dizajniranje i izbor materijala. Isto tako je značajan i izbor tehnike kojom se prati in vivo njihova sudbina i biokompatibilnost. Cilj ove studije je bila procena mogućnosti praćenja biokompatibilnosti dva novo dizajnirana karbonska vlakna pomoću magnetic resonance imaging (MRI). Analizirali smo interakciju karbonskih vlakana sa funk- 
cionalizovanom površinom (kiselinom i bazom) sa mišićnim i potkožnim tkivom kunića. MRI tehnika se pokazala uspešnom u toku praćenja reakcije okolnog tkiva, i procene biokompatibilnosti nove vrste implanata, jer je uspela da in vivo odvoji hirurški edem od inflamacije. Patohistološka analiza je potvrdila rezultate MRI pokazujući time da MRI ima veliki potencijal za in vivo studije takvih materijala. 